\title{
Employees' Perceptions Towards Internal Communication During Organizational Change Management At Multimedia University Of Kenya
}

\author{
Ali Hassan Idow, Dr. Sammy Yaah Baya, and Dr. Idah Muchunku-Mwenda \\ Department of Journalism and Media, Multimedia University of Kenya \\ DOI: 10.29322/IJSRP.11.08.2021.p11658 \\ http://dx.doi.org/10.29322/IJSRP.11.08.2021.p11658
}

\begin{abstract}
Institutions of higher learning are experiencing rapid changes and as a result they have been challenged to adopt effective change management strategies in order to remain competitive. Effective internal communication is regarded as a vital ingredient in successful management of change as it will affect how organizational leaders engage with employees and achieve change objectives. Several scholars have established that there is need for effective communication with employees especially during organizational change. Therefore, this study attempted to evaluate how employees perceive internal communication during organizational change management at Multimedia University of Kenya (MMU).
\end{abstract}

Index Terms: Change, Communication, Internal Communication, Change Communication, Organizational Change

\section{INTRODUCTION}

he main thrust of this paper is to evaluate employees' perceptions towards internal communication during organizational change Tmanagement at Multimedia University of Kenya (MMU). The central question of this paper is how do employees perceive internal communication during organizational change management at MMU?

Communication has been recognized as an important component during a change process in organizations (Kotter, 1996). Quality communication determines the success of a change program during the change process (Hargie \& Tourish, 2009) and increases acceptance, openness and commitment to change (Christensen, 2014). Continuous and frequent communication about change efforts could prove to be valuable in lessening employees' mistrust and uncertainty about the change program (McCabe, 2011). Higher levels of communication satisfaction increases employees' participation during organizational change process (Goris, 2007). The participation of employees in the decision making process is a sign that management trusts them (Erturk, 2008).

Effective internal communication affects the engagement process between organizational managers and employees and this is crucial in achieving organizational objectives (Welch \& Jackson, 2007). Communication and engagement are at the heart of any successful change initiative. Thorough plans for implementing change may well be in place. Different levels of engagement and commitment are required depending on where people are along the change journey. This calls for a mix of approaches and levels of communication along the way. A well-thought-out and structured approach to communication and engagement ensures that the right level of interaction occurs with the right people, at the right time, in an efficient way (Richard et al., 2015).

In Kenya, institutions of higher learning are experiencing rapid changes including, transforming from polytechnics to university colleges, implementing the private sponsorship scheme as an alternative financing strategy, introducing demand driven courses, distance learning programmes, in-service programmes, two semester systems, prudent financial management information systems among many This publication is licensed under Creative Commons Attribution CC BY. 
other changes (Gaunya, 2014). Due to these changes, institutional management have been challenged that there is need to amend institutional vision and mission statements, uphold transparency, evaluate effects of new sources of funding, and meet the requirements for national, regional and international integration (Lemaitre, 2009).

Multimedia University of Kenya (MMU) is one of the 31 public universities in Kenya (CUE, 2020). It is a chartered public university with a rich and distinct history. The university's main campus is located along Magadi Road, approximately 20 Kms South West of Nairobi City Centre (MMU, 2017). The University was chartered as a Public University on 1st March 2013 by virtue of the Universities Act No. 42 of 2012 and the Multimedia University Charter, 2013. On achieving the university status, MMU has undergone transformational changes in terms of organizational structure, academic programmes and infrastructural development. MMU currently has an appropriate organizational structure to enhance management, improve reporting and facilitate communication, has 6 faculties, 12 departments and 3 directorates offering Post Graduate, Degrees, Diploma and Certificate programmes (MMU, 2017).

\subsection{Problem Statement}

Change is a feature that organizations cannot avoid since it has a continued presence in the organizational life (Murugi \& Ongoto, 2018), therefore, appropriate response strategies need to be put in place to enable organizations become efficient, effective and compete favorably (Burnes, 2004). Communication is regarded as one of the appropriate response strategies which should be part of the organizational strategies, objectives and responding to the changing nature of the organization's environment (Armstrong, 2009). During organizational change processes, many organizations do not utilize effective communication and expect everyone to understand proposed changes (Yazdanifard, 2014). Communication approaches to change are still underdeveloped, and there is currently a lack of communication scholars in the field (Johansson \& Heide, 2008). "Research on change implementation is wanting of a communication perspective, which would enhance understanding of implementation activities and there is need for a reconceptualization of the implementation of planned organizational change as a communication-related phenomenon" (Lewis \& Seibold, 1998, p. 94).

Locally, few studies have focused on the role of communication during organizational change management specifically in the new public universities in Kenya. Mutiso (2017) analyze the effect of change management communications teams in influencing staff motivation in a change process using PS Kenya's Orion Project. Gachungi (2014) and Chepkirui (2014) studies have focused on establishing the relationship between communication strategy and change management at Unilever Limited and effective change communication strategies at the workplace at Unilever Tea Kenya respectively. Omitto's (2013) study aimed at establishing employee perceptions of change management at Kenya Commercial Bank (KCB).

MMU, which was awarded charter in March 2013 to be a fully-fledged public university, was experiencing growth in both structural, infrastructural, and academic programmes. The desire to grow, remain competitive and be a leading public university in Kenya presents daunting challenges. It experienced challenges of complex communication procedures, leadership and stakeholder participation that constrained achievement of its planned change activities (MMU, 2017). Due to this fact, there was a compelling need for this research to be undertaken to examine the influence of strategic communication in managing organizational change at MMU.

\subsection{Objective of the Study}

The study was guided by the following research objective:

1) To evaluate employees' perceptions towards internal communication during organizational change management at MMU.

\section{THEORETICAL BACKGROUND (LITERATURE REVIEW)}

\subsection{Kurt Lewin's Change Management Theory}

Kurt Lewin is one of the prominent figures in the field of social psychology and has abundantly researched on the aspect of human changes (Aziz et al., 2017). Lewin was an altruistic who believed that human condition could be improved only by resolving social 
conflict whether it is religious, racial, marital or industrial (Marrow, 1969). He believed that only the permeation of democratic values into all facets of society could prevent the worst extreme of social conflicts and that key to resolving these conflicts was to facilitate planned change through learning (Allport, 1948). Lewin's planned approach to change comprised of four elements: Field theory, Group Dynamics, Action research and the 3 step model of change (Bumes, 2004a).

Although they were treated as separate elements, Lewin saw them as a unified whole to bring about planned change (Allport, 1948). These four elements were conceived as an integrated approach to analyzing, understanding and bringing about planned change at the group, organizational and societal levels (Lewin, 1946). Lewin proposed a three stage theory of change encompassing three distinct phases of implementing change; unfreeze, change (move) and refreeze and it reflects momentous stages in change implementation process (Hussain et al., 2016; Bozak, 2003). It has been utilized extensively in several empirical researches for examining organization changes (Norshidah, 2011). Kurt Lewin views behavior as a dynamic balance of forces working in opposing directions - where driving forces facilitate change because they push employees in the desired direction while restraining forces hinder changes (Kritsonis, 2005).

The success of a change initiative is determined by the quality of communication and according to Klein (1996) the communication strategy (objectives and needs) should match with the general stages of Lewin's change management theory. During the unfreezing stage, an understanding of the difficulties related to the identified problems are sought, strengthening the driving forces and weakening those forces that restrain or oppose change (Bozak, 2003). "The primary communication objective during this stage is to prepare or ready employees and the organization for change as resistance to change will increase at the same rate with how big the change is and how much it affects the organization" (Husain, 2013, p. 44). This step has been identified as "readying" the organization (Cummings \& Huse, 1989). A properly designed communication strategy will help in overcoming this resistance (Klein, 1996). The first communication should come from the top management like a CEO or if it is confined to a specific sub unit, it should be the unit manager to communicate (Young \& Post, 1993). This communication should provide a specific rationale such as a discrepancy between the desired outcomes and actual outcomes (Husain, 2013). During this stage, face-to-face communication is regarded an effective means of communication (Klein, 1996).

Husain (2013) argues that during the move or change stage, a lot of organizational activities happen due to implementation of change and it is during this stage that levels of uncertainty and rumors appear as most of employees are not directly involved in the change process and do not know what is exactly happening. During the planning and implementation of change, it is advisable to involve all relevant key organizational stakeholders (Hussain et al., 2016). The study by Pierce et al. (2002) states that for effective change process, employees must have to be addressed about change; leaders should educate, communicate, participate, involve, take support, provide emotional support and incentives to employees. Therefore, according to Husain (2013) the communication objectives during this stage are; to provide those not involved in the change implementation with detailed and accurate information of what is happening; to provide those involved in the process with information about their roles in the change process, as well as information about how the change will affect them, and their new roles and responsibilities; and to dismiss all the misinformation that is circulating through the organization.

During the unfreezing stage, the change of the current state of the organization to the desired state will not occur quickly but simultaneously (Hussain et al., 2016). The primary organizational objectives during this stage include building structures and processes that support the new ways (Katz \& Kahn, 1978). The communication activities during this final stage are centered on answering employees' questions regarding efficiency, rewards, and relationship roles with communication responsibility shifting from to management to the supervisory management. The information flow should be continuous, concrete and multidirectional, so that employees have enough understanding of the personal implications of change (Husain, 2013). Because of the inevitable misunderstandings that may occur in this stage, communication should primarily concentrate on making public the success of the change and spread the word to employees (Klein, 1996) as most authors recommended that both good and bad news should be delivered.

Managers should encourage new reforms by training workers, delegating, promoting, rewarding and recognizing employee efforts 
towards implementation of reforms (Sarayreh, Khudair, \& Barakat, 2013). This theory argues that all employees should comprehend what is expected of them correctly during any change process and keep a strong focal point in the area of communication, accountability and transparency (Cummings, Bridgman, \& Brown, 2016). According to Murugi and Ongoto (2018), effective communication between the top level managers and lower level employees promote implementation of reforms in any organization. Interaction in the planning process for reforms is essential as well as it gives an opportunity to minimize change resistance in the system. For systemic and individual acceptance of reforms, employees are the key determinants of any successful change (Burnes \& Cooke, 2013). It is very rational, goal and plan oriented (Kritsonis, 2005).

This theory will be applicable in this study since adopting response strategies during organization change management is regarded important for survival. Institutions of higher learning especially MMU, undergo changes and in order to enhance growth and remain competitive, adopting appropriate strategic change management practices such as promoting communication and participation, employee engagement and empowerment, motivational communication and creating a change vision is fundamental. In the world of competition, public universities like any commercial entity have to embrace strategic practices in order to enhance their competitiveness in service delivery (Murugi \& Ongoto, 2018).

\subsection{Social Exchange theory}

Social exchange theory is a prominent theoretical paradigm for understanding workplace relationships (Cropanzano \& Mitchell, 2005) and employee attitudes (DeConinck, 2010). It is not a single theory but is better understood as a family of conceptual models (Cropanzano \& Mitchell, 2005). Social exchange theory is a foundational theory for other theories including leader-member exchange theory (Abu Bakar, Dilbeck, \& McCroskey, 2010), organisational support theory (Baran, Shanock, \& Miller, 2012), transformational leadership (Judge, Piccolo, \& Ilies, 2004), and trust (Dirks \& Ferrin, 2002).

Internal communication has been described in the context of social exchange theory (Karanges, 2014) and this theory stipulates that individuals participate in mutually dependent relationships, meaning the various parties in the relationship have some reasons to engage in exchanges to obtain resources of value; a desire to increase gain and avoid loss; and some degree of continuance of the relationship over time rather than a one-time encounter (Cook, Cheshire, \& Gerbasi, 2006). Ward and Berno (2011) argue that in mutually dependent relationships, obligations are generated through a series of interactions between parties who are in a state of reciprocal interdependence. Mutually dependent interactions are believed to foster quality relationships within the work environment context (Sluss, Klimchak, \& Holmes, 2008).

The concept of interdependence requires bidirectional exchange to take place, which is, something has to be given and something returned (Cropanzano \& Mitchell, 2005). According to Molm (1994) interdependence is believed to foster cooperation among individuals within organizations. This theory describes how the provision of valued resources from an external party (for example, resources from the organisation) results in employees developing a felt obligation to reciprocate with pro-social attitudes and engagement-related behaviors (Blau, 1964). Reciprocity is the most significant characteristics of social exchange relationships, whereby positive and fair exchanges between two parties (individuals or groups) result in favorable behaviours and attitudes (Cropanzano \& Mitchell, 2005). Employees experience social exchange relationships with their colleagues, customers, suppliers, direct supervisor, and their organisation (Masterson, Lewis, Goldman, \& Taylor, 2000). Each of these relationships has cognitive, emotional and behavioral impacts whereby employees reciprocate the socio-emotional benefits they receive (Blau, 1964).

The two social exchange relationships in an employee's professional life are the relationships with their organisation and their direct supervisor (Sluss, Klimchak, \& Holmes, 2008). An employee's desire to reciprocate favors towards their organisation and their direct supervisor are the result of these relationships (Cropanzano \& Mitchell, 2005). Internal communication facilitates interactions between an organisation and its employees which creates a social relationship based on meaning and worth (Smidts, Pruyn, \& Van Riel, 2001). This leads to increased productivity and drive positive employee attitudes (Cropanzano \& Mitchell, 2005). 
Internal communication is focused on achieving the desired outcomes such as employee engagement and commitment (Neill, 2018) with engagement focusing on discretionary efforts exhibited by employees (Saks, 2006). Poor communication within the organization results to disengagement (Welch, 2012). Blau's (1964) conceptualization of social exchange theory classifies information as a resource exchange, which includes, advice, opinions, instructions or enlightenment (Foa, 1971) and is conceptualized as internal communication (Karanges, 2014). Keeping employees engaged is likely more difficult during times of organizational change due to the uncertainty present in the workplace as well as the range of emotions experienced by employees such as anger, resentment, and frustration (Luo \& Jiang, 2014).

Since resistance to change is regarded as one of the biggest problems to the successful management of change (Palmer, 2004). The outcomes that are achieved in the implementation of planned organizational changes depend in part on the interactions and engagement of change leaders and other important stakeholders like employees (Lewis, 2007). Vance (2006) believes that the greater employee engagement, the more likely the employee will 'go extra mile' and deliver a good job performance. Dubin (1968) indicated that involving employees at each and every stage of the change process is vital to enable them own the process and be part of it. Therefore, continued engagement of employees in every activities of the organization, especially during change, will result in positive behavior and attitudes among employees, readying them for change and hence successful implementation of change.

This theory will be applicable in this study since information, which is internal communication, as a resource exchange of communication between organizational management and employees will enhance engagement within the organization and build mutual interdependence among organizational members. When this is achieved, the working environment will improve as a result of positive employees' behaviors and this will be beneficial especially during organizational change resulting into effective management and implementation of change.

\subsection{REVIEW OF LITERATURE}

\subsubsection{Employees' perceptions towards internal communication}

Internal communication will be enhanced and strengthened if there is flow of information in the organization and this will ensure everyone in the organization has a common goal, which is, ensuring the organization's competitive advantage (Rajala, 2011). Effective internal communication in the organization will affect the ability of strategic managers to engage employees and achieve objectives (Welch \& Jackson, 2007). Organizations are highly encouraged to build long-term relationships with employees as much as they do with customers and this is done through developing internal communication and ensuring it functions well and effectively, which affects and enhances the organization's reputation (Croft \& Dalton, 2003).

Developing internal communication is a current topic in many organizations and there is need for good communication with employees (Quirke, 1996). He further notes that employees' research consistently show that majority of employees do not know where their organizations are going and what they are trying to achieve - organizations need more information than before. Some of the barriers to effective internal communication practice include; how much information people need to do their jobs, problems with the sources from which they receive it, the channels through which it is transmitted and how much information is in turn sent by employees (Robson \& Tourish, 2005). Organizations are reluctant to investigate their internal communication practices and therefore there is need for a good research on employees' perceptions on internal communication channels and other strategies (Rajala, 2011).

Coordination of internal communications is needed in organizations since most of them cannot handle internal communication on their own (Quirke, 1996; Robson \& Tourish, 2005). This shows the importance of internal communication in organizations and the benefits of listening to employees and taking their ideas and perceptions into account especially when developing different issues and operations (Pollitt \& Brown 2008). Employee involvement during decision making, planning processes and measuring their opinions is no longer an occasional concession but a necessity for organizational management (Goudge, 2006; Smythe, 2007). Therefore, it is noted that 
employee perceptions provide a lot of insight for internal communication development.

\subsubsection{Empirical Review and Critique of Existing Literature}

Communication is regarded as a vital ingredient to the effective implementation of organizational change (Lewis \& Seibold, 1998). Communication process and organizational change implementation are inextricably linked processes (Lewis, 1999). It is therefore evident that there is an interdependent relationship between communication and organizational change management. Various empirical studies have been conducted on communication and organizational change management. Some of the studies have consistently cited that quality communication is a key determinant of successful management of any organizational change. In her study, Mutiso (2017) aimed to analyze the effect of change management communications teams in influencing staff motivation in a change process using PS Kenya's Orion Project. The study analyzed whether a change management communications team can positively motivate staff to participate in a change process. The findings of the study found that the role of communication in change management was very crucial in creating a positive attitude about the change among employees. The use of various communication channels such as branding, events, special sessions, emails, milestone celebrations etc. breaks monotony and helps to keep people engaged. The study recommends that organizations undergoing change institute change management communication medium to link the change and the people so as to change their attitudes and increase their adaptation to the change.

Owuor (2015) conducted a case study to establish the effects of change management practices on performance at Kenya Bureau of Standards (KEBS). The study's objectives were to establish the practices deployed in management of change and to establish the relationship between change management practices and performance in KEBS. The study concluded that communication is paramount in raising levels of understanding of the strategic change management practices. Communication makes it possible for everybody in the organization including the management staff, the employees among others to know their role in the strategic management process. Gachungi (2014) in her study aimed at establishing the effect of communication strategy on change management at Unilever Kenya Limited. The study observed that communication plays an important role in the success of change management including quick acceptance and reduced resistance. It also observed that choosing the right message, the right media, sender and creating the right environment for communication for any change can be highlighted as major contributing factors that give high chance of success and little chance of resistance to change. The study concludes that it is through communication that employees understand the change and obtain clarity on the impact of the change. It is also through communication that employees get an opportunity to provide their input, comments and feedback to management in regards to the change.

Chepkirui (2014) did a descriptive survey study aimed at investigating effective change communication strategies at Unilever Tea Kenya. The results of the study revealed that employees were satisfied with information regarding the change, their concerns addressed satisfactorily and were part of the implementation process. It also revealed that some strategies were effective than others with wordof-mouth as the most effective strategy. A number of communication channels were provided through which employees can obtain information as well as conveying it, as one strategy to evaluate feedback. Supervisory communication was rated highly by employees as an effective communication strategy. Therefore, the results of this study could help managers in understanding the modern employee conceptualization of effective change communication and the choice of communication strategies to pass change information to employees.

Omitto's (2013) study aimed at establishing employee perceptions of change management at Kenya Commercial Bank (KCB), Nairobi County. The study found that leadership, communication, organisation culture, change agents and employees' readiness to accept change are all great factors of change management at KCB. It concluded that communication helps people work through their concerns. Therefore, the study recommended that there is need to urgently create an organization wide communication/feedback loop that will ensure efficient communication is maintained between the management and employees, thus ensuring immediate action can be taken upon feedback. This will indeed accelerate the change management process. Further the study found that employees perceive 
organizational change as a challenge because of lack of clear vision that governs change, poor organizational structure causing resistance to change, lack of proper knowledge and system incompatibility.

In Kenya and from the above studies, there have been several attempts to understand the role of communication in various industries in the management of organizational change. However, no attempt has been made to understand the role of strategic communication as a key determinant in organizational change management in Kenyan universities, Multimedia University of Kenya (MMU) in particular, thus creating knowledge gap that this study seeks to fill. Other related studies have been done on influence of communication on organizational change management in other settings. Due to time and other environmental changes, the findings of this study could be different from the findings of other studies.

\section{RESEARCH METHODOLOGY}

\subsection{Sampling Design and Sample Size}

The study targeted non-teaching staff spread across 39 departments at MMU. They were drawn from permanently employed, casual and temporary employees. There was a total of 389 non-teaching staff at MMU (MMU, 2017), out of this a sample size of 194 non-teaching staff was selected and picked through simple random sampling. The sample size was determined using the Krejcie and Morgan formula (1970) and shown below.

\begin{tabular}{|c|c|c|c|}
\hline Departments & Total & Departments & Total \\
\hline Chancellor's Office & 2 & Performance Contracting & 3 \\
\hline y VC/AF \& P Office & 2 & Legal Department & 1 \\
\hline y VC/AA/R \& I Office & 2 & Security Department & 10 \\
\hline rar Academic Affairs & 2 & Quality Assurance & 2 \\
\hline rar Administration & 2 & Examinations & 5 \\
\hline ee Department & 6 & Dean of Students & 5 \\
\hline n Resource Department & 5 & Sports & 1 \\
\hline Board & 3 & Library & 5 \\
\hline al Audit & 5 & Printing/Laundry & 7 \\
\hline rate Affairs & 6 & Procurement & 7 \\
\hline sions & 7 & Clinic & 7 \\
\hline epartment & 5 & Hostels & 10 \\
\hline ng \& Quality Management Systems & 2 & Estate & 10 \\
\hline oort & 7 & Main Kitchen & 10 \\
\hline Club House & 7 & ICT Museum & 2 \\
\hline rch \& Innovation & 6 & Directorate Of Postgraduate Studies & 2 \\
\hline $\mathrm{L}$ & 2 & Faculty of Engineering \& Tech. & 7 \\
\hline $\mathrm{y}$ of CIT & 7 & Faculty of Science \& Tech. & 6 \\
\hline $\mathrm{CO}$ & 9 & Faculty of Social Sciences \& Tech. & 2 \\
\hline y of Business \& Economics & 5 & & \\
\hline & 194 \\
\hline
\end{tabular}




\section{Table 1: Sample size}

\subsection{Data Collection and Analysis}

Primary data was collected using questionnaires. The data collection procedure involved the researcher self-administering hard copies of questionnaires to respondents and the soft copy ones sent via email and WhatsApp. The data was checked for completeness and errors, then entered in Statistical Package for Social Science (SPSS). The study used descriptive analysis to evaluate the data on employees' perceptions towards internal communication during organizational change management at MMU.

\section{FINDINGS AND DISCUSSIONS}

The findings in this study are presented using tables for ease of understanding and analysis. Further, measures of central tendency such as frequency, mean, percentage and standard deviation was used to ascertain average responses. The findings are presented in table 2 .

The objective of this study was to examine employees' perceptions towards internal communication during organizational change management at MMU. In order to achieve this, the study adopted a five point likert scale in which respondents were requested to indicate the extent to which they agree with some statements in this variable. The findings are tabulated in the table below, summarizing descriptive analysis of this variable by using frequency, percentage, mean and standard deviation. First, majority $28.6 \%$, did not agree with communication between top management and employees being a two-way, continuous and transparent process. There is a strong relationship between management's interpersonal communication and employees' trust (Jo \& Shim, 2005). According to DuFrene and Lehman (2014), employees want to see and talk to their leaders in times of uncertainty. The organization management need to set the tone for effective internal communication (Tourish \& Robson, 2003). Secondly, 38.1\% of respondents agreed that communication between heads of departments and employees is a two-way, continuous and transparent process. This finding is supported by Rajala (2011) who established that communication between heads of departments and employees succeeds quite well.

Further, $42.3 \%$ of respondents did not agree with internal communication tools being used effectively and efficiently to transmit change messages during the change process at MMU. According to Mazzei (2010), internal communication is no longer a message-targeting function, instead it should be key in encouraging active employee behaviors in addition to delivering messages. A further $36.9 \%$ of respondents did not agree with MMU employees being engaged completely during organizational change process. In their study, Abdi and Rathmaya (2017) found that employees expressed that information about change before decision making by the management, increases their engagement, motivation, trust and involvement. In addition, 32.7\% of the respondents strongly disagreed that MMU management seriously considered their recommendations on change initiatives. According to Rajala (2011), there is a big role in encouraging employees to communicate and share their ideas and opinions during change process.

On policies and procedural changes that impact their job, 32.1\% of respondents agreed that MMU management communicates effectively to them. The goal of change communication should address what the changes mean for employees and how it affects their jobs (Neill, 2018). However, 36.9\% of respondents did not agree with changes caused by internal forces (e.g. personnel changes) being communicated effectively to them. Meaningful communication informs and educates employees at all levels and motivates them to support the change strategy (Barrett, 2002). Majority (37.5\%) of the respondents agreed that changes caused by external forces (e.g. government regulations, the economy etc.) are communicated effectively to them.

When changes occur at MMU, 31.5\% of respondents agreed that they are the last to know about it. In their study, Abdi and Rathmaya (2017) found that the most important factor in employee engagement during change is open and transparent communication as this will help to avoid mistrust and misunderstanding. In addition, majority $31.5 \%$ of respondents agreed that challenges in internal communication has led to ineffective management of change in MMU. This finding is supported by Bordia, Hunt and Paulsen (2004) who indicated that many organizational changes fail due to shortcomings in the internal communication and that it is an important component of change processes in organizations (Abdi \& Rathmaya, 2017).

This publication is licensed under Creative Commons Attribution CC BY. 
Table 2: Descriptive Analysis of variable Employees' Perceptions towards in Internal Communication during Organizational Change Management at MMU.

\section{CONCLUSION}

The results of the findings revealed that internal communication practices at MMU is wanting since employees are not communicated to sufficiently during organizational change process. Employees are also not involved and engaged during organizational change process. This study concludes that effective internal communication is crucial in the implementation of change initiatives communicating to employees early, consistently, and it should be transparent, they should also be engaged and involved in the decision

\begin{tabular}{|c|c|c|c|c|c|c|c|c|}
\hline \multicolumn{9}{|c|}{$n=168$} \\
\hline $\mathbf{S} / \mathbf{N}$ & & 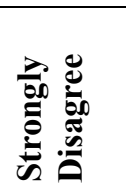 & 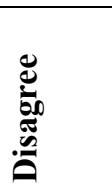 & $\begin{array}{l}\bar{T} \\
\bar{\Xi} \\
\bar{Z}\end{array}$ & $\underset{0}{20}$ & 党范 & $\sum^{\bar{E}}$ & 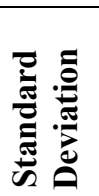 \\
\hline 1. & $\begin{array}{l}\text { Communication between top management and employees } \\
\text { is a two-way, continuous and transparent process }\end{array}$ & $26.2 \%$ & $28.6 \%$ & $23.2 \%$ & $19.0 \%$ & $3.0 \%$ & 2.44 & 1.157 \\
\hline 2. & $\begin{array}{l}\text { Communication between heads of departments and } \\
\text { employees is a two-way, continuous and transparent } \\
\text { process }\end{array}$ & $7.7 \%$ & $12.5 \%$ & $26.8 \%$ & $38.1 \%$ & $14.9 \%$ & 3.40 & 1.122 \\
\hline 3. & $\begin{array}{l}\text { Internal communication tools are used effectively and } \\
\text { efficiently to transmit change messages during the change } \\
\text { process }\end{array}$ & $16.1 \%$ & $42.3 \%$ & $14.9 \%$ & $22.6 \%$ & $4.2 \%$ & 2.57 & 1.130 \\
\hline 4. & $\begin{array}{l}\text { MMU employees are engaged completely during } \\
\text { organizational change process }\end{array}$ & $26.8 \%$ & $36.9 \%$ & $22.0 \%$ & $11.9 \%$ & $2.4 \%$ & 2.26 & 1.057 \\
\hline 5. & $\begin{array}{l}\text { You believe that your recommendations on change } \\
\text { initiatives are considered seriously by the top } \\
\text { management }\end{array}$ & $32.7 \%$ & $29.2 \%$ & $23.2 \%$ & $12.5 \%$ & $2.4 \%$ & 2.23 & 1.109 \\
\hline 6. & $\begin{array}{l}\text { Policies and procedural changes that impact my job are } \\
\text { communicated effectively }\end{array}$ & $14.9 \%$ & $24.4 \%$ & $22.0 \%$ & $32.1 \%$ & $6.5 \%$ & 2.91 & 1.193 \\
\hline 7. & $\begin{array}{l}\text { Changes that are caused by internal forces (e.g. personnel } \\
\text { changes) are communicated effectively }\end{array}$ & $23.2 \%$ & $36.9 \%$ & $17.9 \%$ & $19.6 \%$ & $2.4 \%$ & 2.41 & 1.118 \\
\hline 8. & $\begin{array}{l}\text { Changes that are caused by external forces (e.g. } \\
\text { government regulations, the economy etc.) are } \\
\text { communicated effectively }\end{array}$ & $10.1 \%$ & $16.1 \%$ & $25.6 \%$ & $37.5 \%$ & $10.7 \%$ & 3.23 & 1.151 \\
\hline 9. & $\begin{array}{l}\text { When changes occur at MMU, I am the last to know about } \\
\text { it }\end{array}$ & $13.7 \%$ & $17.3 \%$ & $22.6 \%$ & $31.5 \%$ & $14.9 \%$ & 3.17 & 1.270 \\
\hline 10. & $\begin{array}{l}\text { Challenges in internal communication has led to } \\
\text { ineffective management of change in MMU }\end{array}$ & $6.0 \%$ & $11.9 \%$ & $24.4 \%$ & $31.5 \%$ & $26.2 \%$ & 3.60 & 1.169 \\
\hline 11. & Overall Average & & & & & & 2.82 & 1.148 \\
\hline
\end{tabular}

making process, and their opinions to be considered by the organizational top management. This will lead to increased efficiency and successful implementation of a change program, hence, avoiding resistance to change.

\section{RECOMMENDATION}

MMU management should ensure the practice of internal communication during organizational change process is effective - the communication process between management and employees should be two-way, transparent, and that employees are engaged in the This publication is licensed under Creative Commons Attribution CC BY. 
decision making process and their opinions taken into consideration as this will ensure increased efficiency and successful implementation of a change program, hence, avoiding resistance to change.

\section{References}

Abdi, S., \& Rathmaya, N. (2017). Managing employees and promoting internal communication during change: A case study of change management at MTR Tunnelbanan AB. Sweden: Malardalen University.

Abu Bakar, H., Dilbeck, K. E., \& McCroskey, J. C. (2010). Mediating role of supervisory communication practices on relations between leader-member exchange and perceived employee commitment to workgroup. Communication Monographs, 77(4), 637-656.

Allport, G. W. (1948). Foreword. In G. W. Lewin (eds), Resolving Social Conflict. London: Harper \& Row.

Armstrong, M. (2009). Armstrong Hand Book on Performance management, (3rd ed) . UK : Koga Page Ltd. .

Aziz et al. (2017). The Application of Kurt Lewin's Model of Change in the Implementation of Higher Order Thinking Skills in School. International Journal of Academic Research in Business and Social Sciences, 2017, Vol. 7, No. 8, ISSN: 2222-6990, 109-115.

Baran, B. E., Shanock, L. R., \& Miller, L. R. (2012). Advancing organizational support theory into the twenty-first century world of work. Journal of Business and Psychology, 27(2), 123-147.

Barrett, D. J. (2002). Change communication: using strategic employee communication to facilitate major change. Corporate Communications: An International Journal, 7 (4), 219-230.

Blau, P. M. (1964). Exchange and power in social life. New York: John Wiley.

Bordia, P., Hunt, E., \& Paulsen, N. (2004). Uncertainty during organizational change: Is it all. European Journal of Work and Organizational Psychology, 21.

Bozak, M. (2003). Using Lewin's force field analysis in implementing a Nursing information system. Computers, Informatics, Nursing, 21(2), 80-85.

Bumes, B. (2004a). Kurt Lewin and the planned approach to change: a reappraisal. Journal of Management Studies, Vol. 41, No. 6, 972-1002.

Burnes. (2004). Managing Change: A Strategic Approach to Organizational Dynamics, (4th Ed). Harlow Essex: Prentice Hall.

Burnes, B., \& Cooke, B. (2013). Kurt Lewin's field theory: A review and re-evaluation. International Journal of Management Reviews, 15 (4), 408-425.

Chepkirui, R. J. (2014). Operations and Change Communication in organizations: A case study of Unilever Tea Kenya. Nairobi: University of Nairobi.

Christensen, M. (2014). Communication as a Strategic Tool in Change Processes. International Journal of Business Communication. Vol. 51 (4), 359-385.

Cook, K. S., Cheshire, C., \& Gerbasi, A. (2006). Power, dependence and social exchange. In P. J. Burke, Contemporary Social Psychology Theories (pp. 194-216). Stanford, CA: Stanford University Press.

Croft, S., \& Dalton, J. (2003). Managing Corporate Reputation: The New Currency. London: Thorogood Publishing.

Cropanzano, R., \& Mitchell, M. S. (2005). Social exchange theory: An interdisciplinary review. Journal of Management, 31(6), 874900.

CUE. (2020, June 11). CUE. Retrieved from CUE: http://www.cue.or.ke/

This publication is licensed under Creative Commons Attribution CC BY.

http://dx.doi.org/10.29322/IJSRP.11.08.2021.p11658

WWW.ijsrp.org 
Cummings, S., Bridgman, T., \& Brown, K. G. (2016). Unfreezing change as three steps: Rethinking Kurt Lewins legacy for change management. Human Relations, 69(1), 33-60.

Cummings, T. G., \& Huse, E. (1989). Organization Development and Change, 4th ed. West, St. Paul, MN.

DeConinck, J. B. (2010). The effect of organizational justice, perceived organizational support, and perceived supervisor support on marketing employees' level of trust. Journal of Business Research, 63(4), 1349-1355.

Dirks, K. T., \& Ferrin, D. L. (2002). Trust in leadership: Meta-analytic findings and implications for research and practice. Journal of Applied Psychology, 87(4), 611-628.

Dubin, A. (1968). How Change Works. New York: Prentice-Hill.

DuFrene, B. D., \& Lehman, C. M. (2014). Navigating Change: Employee Communication in Times of Instability. Business and Professional Communication Quarterly, Vol. 77 (4), 443-452.

Erturk, A. (2008). A trust-based approach to promote employees' openness to organizational change in Turkey. International Journal of Manpower, 29(5), 462-483.

Foa, U. G. (1971). Interpersonal and economic resources. Science, 171(3969),, 345-351.

Gachungi, S. W. (2014). Effect of Communication Strategy in Change Management at Unilever Kenya Limited. [S1].

Gaunya, C. R. (2014). An Evaluation of Change Management and Its Implications on Competitiveness of Public Universities in Kenya. European Journal of Business and Management. ISSN 2222-1905 (Paper) ISSN 2222-2839 (Online) Vol.6, No.37, 179-188.

Goris, J. R. (2007). Effects of satisfaction with communication on the relationship between individual - job congruence and job performance/satisfaction. Journal of Management Development, 26:8, 737-752.

Goudge, P. (2006). Employee Research: How to Increase Employee Involvement Through Consultation. London: Kogan Page Limited.

Hargie, O., \& Tourish, D. (2009). Auditing Organizational Communication. [S1]: Routledge.

Husain, Z. (2013). Effective communication brings successful organizational change. The Business \& Management Review, Vol.3 (2), 43-50.

Hussain et al. (2016). Kurt Lewin's process model for organizational change: The role of leadership and employee involvement: A critical review. Journal of Innovation \& Knowledge. DOI: 10.1016/j.jik.2016.07.002, 123.

Jo, S., \& Shim, S. W. (2005). Paradigm shift of employee communication: The effect of management communication on trusting relationships. Public Relations Review, 31, 277-280.

Johansson, C., \& Heide, M. (2008). Speaking of change: three communication approaches in studies of organizational change. Corporate Communications: An International Journal, Vol. 13 Iss 3, 288 - 305.

Judge, T. A., Piccolo, R. F., \& Ilies, R. (2004). The forgotten ones? The validity of consideration and initiating structure in leadership research. Journal of Applied Psychology, 89(1), 36-51.

Karanges, E. R. (2014). Optimizing employee engagement with internal communication: A Social Exchange Perspective. [S1].

Katz, D., \& Kahn, R. (1978). The Social Psychology of Organizations. New York: John Wiley.

Klein, S. M. (1996). A management communication strategy for change. Journal of Organizational Change Management, 9(2) , 1-12.

Kotter, J. P. (1996). Leading change. Havard: Havard Business School Press.

Krejcie, R. V., \& Morgan, D. W. (1970). Determining Sample Size for Research Activities. Educational and Psychological This publication is licensed under Creative Commons Attribution CC BY. 
Measurement.

Kritsonis, A. (2005). Comparison of Change Theories. International Journal of Management, Business, and Administration, Vol. 8, No. $1,2005,1-7$.

Lemaitre, M. J. (2009). Quality Assurance in a Changing World. INQAAHE Conference. Abu Dhabi.

Lewin, K. (1946). Action research and minority problems. London: Harper \& Row.

Lewis, L. K. (1999). Disseminating information and soliciting input during planned organisational change: Implementers' targets, sources, and channels for communicating. Management Communication Quarterly, 13(1), 43-75.

Lewis, L. K. (2007). An Organizational Stakeholder Model of Change Implementation Communication. Communication Theory ISSN 1050-3293, 176-204.

Lewis, L. K., \& Seibold, D. (1998). "Reconceptualizing organizational change implementation as a communication problem: a review of literature and research agenda". In M. E. Roloff, \& G. Paulson, (Eds) Communication Yearbook, Vol. 21, Sage, Newbury Park, CA, pp. 93-151. (pp. 93-151). Newbury Park, CA: Sage.

Luo, Y., \& Jiang, H. (2014). Effective public relations leadership in organizational change: A study of multinationals in mainland China. Journal of Public Relations Research, 26, 136-160.

Marrow, A. J. (1969). The Practical theorist: The Life and Work of Kurt Lewin. New York: Teachers College Press.

Masterson, S. S., Lewis, K., Goldman, B. M., \& Taylor, M. S. (2000). Integrating justice and social exchange: The differing effects of fair procedures and treatment on work relationships. The Academy of Management Journal, 43(4),, 738-748.

Mazzei, A. (2010). Promoting active communication behaviors through internal communication. Corporate Communications: An International Journal, 15 (3), 221-234.

McCabe, S. (2011). Corporate strategy in construction: Understanding today's theory and practice. New York: Wiley.

MMU. (2017). Strategic Plan (2017-2021). Nairobi: Multimedia University of Kenya.

Molm, L. D. (1994). Dependence and risk: Transforming the structure of social exchange. Social Psychology Quarterly, 57(3),, 163176.

Murugi, N. C., \& Ongoto, K. H. (2018). Strategic management practices and change implementation in selected public universities in Kenya. International Academic Journal of Human Resource and Business Administration (IAJHRBA) | ISSN 2518-2374, 124149.

Mutiso, G. M. (2017). Change Management Communications: A Case of PS Kenya's Orion Project. [S1]: UNITED STATES INTERANTIONAL UNIVERSITY.

Neill, M. S. (2018). Change Management Communication: Barriers, Strategies \& Messaging. Public Relations Journal Vol. 12 Issue 1, $1-26$.

Norshidah, N. (2011). The influence of emotional intelligence, leadership behaviour and organizational commitment on organizational readiness for change in higher learning institution. Procedia - Social and Behavioral Sciences, 29, 129-138.

Omitto, O. A. (2013). Employee Perception of Change Management Practices at Kenya Commercial Bank, Nairobi County. Nairobi.

Owuor, P. R. (2015). Change Management Practices Influencing Performance at Kenya Bureau Standards. Nairobi.

Palmer, B. (2004). Overcoming Resistance to Change . Quality Progress. 37, (4) , 35.

This publication is licensed under Creative Commons Attribution CC BY.

http://dx.doi.org/10.29322/IJSRP.11.08.2021.p11658

WWW.ijsrp.org 
Pierce, J. L., Gardner, D. G., \& Dunham, R. B. (2002). Managing organizational change and development. In Management and organizational behavior: An integrated perspective. Cincinnati, OH: South-Western College Publishing (Chapter 18), 627657.

Quirke, B. (1996). Putting communication on management's agenda. Journal of Communication Management 1.1, 67-79.

Rajala, I. (2011). Developing Internal Communication in Fast-Changing Organizations. [S1].

Richard et al. (2015). The Effective Change Manager's Handbook: Essential guidance to the change management body of knowledge. London: Kogan Page Limited.

Robson, P. J., \& Tourish, D. (2005). Managing internal communication: an organizational case study . Corporate Communications: An International Journal 10.3, 213-222.

Saks, D. (2006). The Design and Use of Management Control Systems: An Extended Framework for Analysis. Working Paper SSRN.

Sarayreh, B. H., Khudair, H., \& Barakat, E. A. (2013). Comparative Study: The Kurt Lewin of Change Management. International Journal of Computer \& Information Technology (ISSN: 2279 - 0764), Volume 02 - Issue 04, July 2013, 626-629.

Sluss, D. M., Klimchak, M., \& Holmes, J. J. (2008). Perceived organizational support as a mediator between relational exchange and organizational identification. Journal of Vocational Behavior, 73(3), , 457-464.

Smidts, A., Pruyn, A. T., \& Van Riel, C. B. (2001). The impact of employee communication and perceived external prestige on organizational identification. Academy of Management Journal, 44(5),, 1051-1062.

Smythe, J. (2007). Employee engagement-its real essence. Human Resource Management International Digest.

Tourish, D., \& Robson, P. (2003). Critical upward feedback in organizations: Processes, problems and implications for communication management. Journal of Communication Management, 8, 150-167.

Vance, S. (2006). Capitalism and Freedom. London: University of Chicago Press.

Ward, C., \& Berno, T. (2011). Beyond social exchange theory: Attitudes toward tourists. Annals of Tourism Research, 38(4),, 15561569.

Welch, M. (2012). Appropriateness and acceptability: Employee perspectives of internal communication. Public Relations Review, 38, 256-254.

Welch, M., \& Jackson, P. R. (2007). Rethinking internal communication: a stakeholder approach. Corporate Communication: An International Journal, Vol. 12 Issue: 2, 177-198.

Yazdanifard, R. (2014). Communication as a Crucial Lever in Change Management. IRACST- International Journal of Research in Management \& Technology (IJRMT), ISSN: 2249-9563, Vol. 2, No. 1, 2012, 52-57.

Young, M., \& Post, J. E. (1993). "Managing to communicate, communicating to manage: how leading companies communicate with employees",. Organizational Dynamics, Vol. 22 No. 1 Summer, 31-43.

\section{AUTHORS}

First Author: Ali Hassan Idow is a lecturer at the faculty of media and communication, and post graduate student at Multimedia University of Kenya. ali.hassan358@gmail.com

This publication is licensed under Creative Commons Attribution CC BY. 
International Journal of Scientific and Research Publications, Volume 11, Issue 8, August 2021

Second Author: Dr. Sammy Yaah Baya, PhD, is a lecturer at the faculty of media and communication at Multimedia University of Kenya. Senior administrative officer at the Kenya Medical Research Institute (KEMRI) and a writer. yaahbaya@gmail.com

Third Author: Dr. Idah Muchunku-Mwenda, $\mathrm{PhD}$, is a senior lecturer and coordinator postgraduate studies, faculty of media and communication, at Multimedia University of Kenya. idahmwenda@gmail.com 